\title{
Building an Anti-Corruption Legal Culture
}

\author{
Kaharuddin Syah ${ }^{*}$ and Abdul Malik
}

\author{
Faculty of Law, Universitas Muhammadiyah Palu, Indonesia
}

\begin{abstract}
Background: Corrupt behaviour in Indonesia is increasingly becoming a culture, which is undoubtedly destructive to the economy and moral order of the nation. Corruption has become a chronic disease in the country, which requires serious treatment, especially by the state.

Objective: Building an anti-corruption culture is a genuine and sustained intention; such an effort should be spearheaded y the government. Instilling an understanding that corruption is a despicable act based on religious and social norms which are not ethical. However, corruption's complexity and its modes or categories have kept on the increase along with the vast power of the state in regulating social life. Various attempts have been made by all the previous governments, but they cannot free the country from the tsunami of corruption.

Approach: Though the various policies and law enforcement models have been put in place, corruption persists today. The strategy of building an anti-corruption legal culture should be continuously promoted, in securing a corruption-free future for Indonesia.
\end{abstract}

Keywords: Anti-corruption, culture building, and free state from the corrupt.

\section{INTRODUCTION}

The escalation of corruption cases in Indonesia has become a difficult phenomenon to fully comprehend. This deviant behavior has occurred structurally, massively, systematically and tends to be institutional, even exposed in judicial institutions that should play the role of anti-corruption enforcement. Corruption, in this case, has become like the COVID 19 disease, slowly spreading to various aspects of national and state life. Corruption practices can be found from the smallest level such as the individual and to higher levels in both government and the private sector. Eradicating corruption is very difficult considering that the corruption culture is inherent in people's lives (Paldam, 2002). Various efforts to eradicate corruption have been carried out with various instruments that included structural overhaul and law enforcement. Relying on law enforcement and government reforms is no longer sufficient given the public perception of acts of corruption that already appear normal. Therefore, eradicating corruption must be done through other alternatives like building an anti-corruption culture (Lukito, 2016). Corruption as a cultural phenomenon can be understood that it occurs because it has become a habit/behavior built based on values that are known, understood and believed by a person or group of people (Stulhofer, 2008), these values are built through systematic socialization and internalization processes. ${ }^{1}$

*Address correspondence to this author at the Faculty of Law, Universitas Muhammadiyah Palu, Indonesia; E-mail: kaharuddinsyahk@gmail.com

${ }^{1}$ Agus Pramusinto, Mencari jalan alternatif Strategi Pemberantasan korupsi, Jurnal Kebijakan dan Aministrasi Publik, Volume 13. Nomor 1 (mei 2009). Hal. 11
Based on a survey conducted by the Transparency International Corruption Perception Index (CPI) in 2018 Indonesia was ranked 38th and was ranked 89th out of 180 countries surveyed (CPI, 2019). This score increased by 1 point from the last survey in 2017. The small shift in position is due to the positive anticorruption efforts carried out by various parties including the government, the Corruption Eradication Commission, the business community, and civil society, although not yet significant. The upward trend in the Corruption Perception Index, which can be said to be very slow, reflects this. In the past four years, Indonesia scored $36,37,37$, and 38 respectively. This score is certainly still far from the target of 50 in 2019 which was set by the government along with the Corruption Eradication Commission (KPK) (Turner, Prasojo, and Sumarwono, 2019). Indonesia's position remains in the $30 \mathrm{~s}$, which is the rank of the most corrupt countries in the world. The main factor of this stagnation lies in the widespread practice of bribery and corruption in the political system such as the buying and selling of votes, money politics, and kleptocracy. Indonesia Corruption Watch (ICW), revealed that the trend of corruption over the past four years (2015-2018) illustrates that the enforcement of corruption cases carried out by law enforcers is based on the number of corruption cases investigated, the number of actors determined as suspect, and the total value of losses to the state. In the release of ICW findings, there were on average 392 cases of corruption handled by law enforcement for 4 (four) years (Sidi, 2019), the average actors determined were 
1,153 , and the average state losses incurred due to corruption amounted to Rp. 4.17 trillion. $^{2}$

The Central Statistics Agency issued official statistics on the 2019 Anti-Corruption Index (IPAK) that the Indonesian anti-corruption behavior stands at 3.70 on a scale of 0 to 5 (Firmansyah, 2021). This figure is higher than the 2018 achievement of 3.66 , where the value of 5 indicates people's anti-corruption behavior and 0 indicates people's permissiveness of corruption. The Anti-Corruption Behavior Index is based on two dimensions, namely Perception and Experience Dimensions (Zouaoui and Ben-Arab, 2017). In 2019, the Perception Index value was 3.80 , a decrease of 0.06 points compared to the 2018 Perception Index (3.86). In contrast, 2019, the Experience Index was 3.65 which rose by 0.08 points compared to the 2018 experience index (3.57). In 2019, the urban population IPAK was high at 3.86 compared to rural communities at 3.49. Communities with higher education levels, tend to be more anti-corruption. In 2019, the IPAK of junior high school level educated people and below was 3.57; and for those above high school level at 4.05. People of age of 40-59 years are the most anti-corruption compared to other age groups. In 2019, the IPAK of people aged 40 years and under amounted to 3.66; age 40-59 years of 3.73; and age 60 years or more at 3.66. Based on Indonesia's ranking position in the Corruption Perception Index (CPI) and ICW, it appears that Indonesia has not been free from the problem of corruption and the public still feels the practice of corruption in Indonesia. Based on the thoughts outlined above, then in writing this article, the main problem to be discussed is how to build an anti-corruption legal culture in Indonesia.

\section{RESEARCH METHOD}

This study used the document analysis qualitative research method (Bowen, 2009). Literature study, a type of library research can be interpreted as a series of activities relating to the collection of library data, reading and recording, and processing research materials. The research material studied formed the secondary data sources that explained the phenomenon of corruption that occurs in the community. Supported by various other sources of literature in the form of research results and reports on corruption from international, and national agencies, as

${ }^{2}$ Indonesia Corruption Watch, Laporan Tren Penindakan Kasus korupsi Tahun 2018. Hal 5 well as various theoretical reference studies from various journals and books. Library research, however, limits its activities to the collection of books with limited or no much research activity in the field.

\section{DISCUSSION}

\section{Anti-Corruption Empirical Study in Indonesia.}

Culture is a blueprint of behavior; it provides guidelines for people's behaviour and actions. According to Saleh and Munif (2015: 311), the general characteristics of culture are learned and passed on, it lives in society, develops, changes, and integrates. Based on the guidelines that citizens adhere to, the community forms procedures in achieving desired goals. Friedman (1975) states that studying the legal system can be approached from three components, namely structure, substance, and culture. Structural components are the parts that move in a mechanism, the substance component is the actual result produced by the legal system and includes unwritten legal methods. While the culture component is the values and attitudes that bind the legal system together and produce a form of law enforcement in the culture of society as a whole. The cultural component plays a very important role in law enforcement especially criminal law. Sometimes the success rate of law enforcement in a community is high because it is supported by community culture. This can be through high public participation in crime prevention, reporting and making complaints of crime, and working with law enforcement officials in crime prevention efforts, although the structure and substance components are not very good; some communities do not want formal procedures to be established as they should. ${ }^{3}$

The anti-corruption movement in Indonesia has long been carried out by the government since the old administrations (Hamilton-Hart, 2001). Various efforts and strategies have been carried out by the government at that time including the enactment of corruption eradication laws and the emergence of countless anti-corruption institutions by both government and civil society. However, the many regulations and anti-corruption bodies/institutions do not guarantee that the nation is free from corruption. Like cancer cells corruption is malignant because of its expanded roots, the more it is treated the faster it

${ }^{3}$ Aprilia Arsyad, Membudayakan Gerakan Anti Korupsi Dalam Rangka Penanggulangan Korupsi di Indonesia (Cultivating the Anti-Corruption Movement in the Context of Combating Corruption in Indonesia), Hal. 47 
spreads (Harrison, 2017). In the 1960s anti-corruption in Indonesia started with the passing of the first anticorruption law. The law gave birth to the AntiCorruption Commission called the State Apparatus Retooling Committee (PARAN), led by General A.H. Nasution assisted by Prof. M. Yamin and Roeslan Abdul Gani (Juwono, 2018). The most important task of this institution was to ensure the requirement of all state officials to fill out the Asset Wealth Register. However, this task failed to be implemented or yield any results. At that time, there were at least four factors causing failure in eradicating corruption. Firstly, there is not yet a derivative policy that allowed policy implementation agents to carry out their duties properly secondly, there was resistance from State officials (especially those indicated as being corrupt) by refusing to submit their list of assets to PARAN. They preferred to hand it only to the president, even though in reality, never submitted their list of assets to the president until PARAN was disbanded. Third, there was no commitment from the State, especially officials to fight and eradicate corruption. After the PARAN institution was dissolved, the old government at the time subsequently issued the Presidential Decree No. 275 of 1963 concerning the eradication of corruption. In the presidential decree, the government reasserted General A.H Nasution as its chairman with a tougher task of forwarding corruption cases to court. In his duties, General A.H Nasution formed Operation Budhi (Belchenko, Kurinin, and Teplov, 2017). The targets were dstate-owned enterprises and institutions which were considered prone to corruption. The Presidential Decree 275 of 1963 as a legal umbrella for the eradication of corruption was also not carried out effectively because of the resistance it faced from state officials close to the President. Up until this anticorruption entity was dissolved, it did not produce meaningful results.

Subsequent governments also attempted to eradicate corruption which had now turned unstoppable and permeated all levels of life and government. President Suharto in his speech to the legislature on August 16, 1967, stated that he would eradicate corruption to its roots (Butt, 2017). Then the government formed the Corruption Eradication Team (TPK), which did not dare to expose the corruption that had plagued the country until 1970 when large-scale demonstrations occurred demanding and urging President Suharto to fulfill his promise to seriously eradicate corruption, especially in Pertamina, Bulog and the Forestry department. Committee Four was then formed and given the task of eradicating corruption, but also failed to do much in controlling the spread of corruption so that the government at that time instituted an operation called OPSIB led by Admiral Sudomo, who also failed to hold back the pace of corruption development. The failure to eradicate corruption in this era was marked by the birth of various rules that were deliberately made to protect the actions of corruptors to be free from the law. The pattern of government that protects corruptors can be clearly understood through a political economy approach to corruption when the attitude of Indonesia was referred to by foreign observers as a kleptocratic State, a term commonly used to refer to a State of the Thieves.

Hamilton hart [2001] in his writings on -anticorruption strategies in Indonesia notes that since the 1998 reforms various efforts to deal with fighting corruption have indeed been carried out fundamentally by the government including through political reform, social and press edom freedoms, fiscal transparency, and financial monitoring, legal reform, direct strategies against corruption, foreign, involvement in the reform process and civil service reform. ${ }^{4}$

In the era of President B.J Habibie, the anticorruption movement was marked by the issuance of Law No: 28 of 1999 concerning the administration of cleaning up corruption from the state. Based on this law several anti-corruption bodies were formed, among others; KPKN, KPPU, and the Ombudsman Commission, however, these institutions were not able to demonstrate their performance as effective anticorruption bodies (Harijanti, 2014). In the era of the government of Abdurahaman Wahid (Gusdur), the corruption eradication movement was realized by forming an anti-corruption body named "joint team to eradicate corruption" (TGPTPK) was formed based on government regulation No. 19 of 2000. But unfortunately, like other before it, the institution led by Supreme Court Judge Andi Andojo eventually had to be dissolved after not showing any significant results in the eradication of corruption (Ulul Albab, 2007). In the era of Megawati's presidency, the commitment to continue fighting corruption also continued, the government formed a commission of corruption eradication (KPK), through Law No. 30 of 2002 (Kinanti, 2020). After being formed, the KPK immediately worked extra hard, the KPK showed itself as an authoritative institution and was feared by officials. Some officials and politicians, especially from 
the legislature, were brought to court on corruption charges.

Then in the era of president Susilo Bambang Yudhoyono (SBY), the anti-corruption movement was continued by forming a Corruption Eradication Team (Tipikor Team), based on Presidential Decree No.61 of 2005. This institution developed a mission to eradicate corruption within the government. Thus, in the era of SBY Indonesia had 2 anti-corruption institutions, namely the KPK, and the Corruption Eradication Team. However, in its development in mid-2007, it was disbanded. KPK's performance in eradicating corruption is very prominent, it has even begun to cause a deterrent effect. Until the end of 2006, many corrupt officials were dragged to court (Choi, 2011). Some of the major corruption cases successfully revealed by the KPK include the case of the sale of credit assets of PT. PPSU by IBRA, cases of misuse of pre-shipment facilities and deposit placement from $\mathrm{BI}$ to PT. Texmaco group through BNI Bank, the case of misuse of position by the head of the finance department of the Director-General in the purchase of land, the case of busway procurement in the Jakarta administration, the case at the Indonesian Embassy in Malaysia, Theo Toemion case, bribery case Supreme Court Justice in the Probosutdejo case, the bribery case of PT Jakarta clerk by attorney Abdullah Puteh, corruption case in KPU, bribery case for KPU members, case for a permit to release forest area of 174 thousand hectares for oil palm plantations, 185 cases for heavy equipment purchases, 63 billion by the government of West Java, the case of Rokhim Dahuri former Minister of Maritime Affairs and Perikana, cases of illegal levies handling immigration documents, the case of procuring ballot boxes for the 2004 elections, the case of former South Kalimantan Governor HM Sjachriel Durham with alleged corruption in the use of tactical money, the corruption case of Kendal district budget. 2003-2005 worth 47 billion, the case of the Regent of Kutai Kartaneg ara Syaukani H, R, with the alleged corruption of the loa Kulu airport, which is estimated to cost the country Rp. 15.9 billion, the BLBI case and the $\mathrm{BI}$ case, the textbooks case in Sleman are currently being handled by the KPK.

Various efforts to eradicate corruption carried out by the authorities since the older governments until SBY$\mathrm{JK}$ in plain view did not show brilliant results, this made corruption appear reasonable as it was associated with a corrupt political and bureaucratic system. So, forming an anti-corruption culture amidst a society that considers corruption as the normal practice is the root of the corruption evil in the State. Corruption awareness efforts as a crime have only been realized since the 1998 reform era regarding the implementation of a clean and corruption-free state. Various anti-corruption bodies have been formed, including the KPKPN, KPPU, and the OMBUDSMAN COMMISSION, and the enactment of law No. 20 of 2001 concerning the eradication of corruption and law number 30 of 2002 concerning the Corruption Eradication Commission. Much as these are good steps taken in eradicating corruption in the current era it takes hard work of all parties, not only the KPK but also all elements of the nation to be directly involved in eradicating corruption. This is expected to eliminate the perception that corruption is a historical and cultural legacy of Indonesian society.

Various regulations that have been put in place, among them the MPR Decree Number XI concerning the implementation of a corruption-free State, Law No. 28 of 1999 concerning Clean and corruption-free Government Implementation, Law No. 31 of 1999 concerning Corruption Eradication, Law No. 20 of 2001 concerning the Anti-Corruption Commission became the main foundation for the formation of the KPK, Law Number 25 of 3003 concerning anti-money laundering crimes which form the basis of the law that established PPATK, Law Number 1 of 2006 which is the basis for reverse proof for cases of alleged corruption, Law Number 7 of 2006 concerning the ratification of the UN convention on anti-corruption is evidence of Indonesia's commitment to join the anti-corruption international community, Law Number 13 of 2006 concerning the protection of witnesses and victims who encourage people to be willing to become whistleblowers, Presidential Instruction Number 5 of 2004 concerning the Acceleration of Corruption Eradication Efforts, Attorney General Circular Number 007 / A / JA / 11/2004 concerning the Acceleration of Corruption Handling in Indonesia, the National Action Plan for Corruption Eradication (RAN PK) 2004-2009 which formulates government action plans in the eradication of Corruption managed by Bappenas in coordination with the relevant Ministries / Nondepartmental Institutions, elements of society and the Corruption Eradication Commission, Circular Letter of the Police Headquarters Number Pol: B / 345 / III / 2005 concerning Priority in Handling Corruption Cases is unable to prevent the rapid growth of corruption in the country (Mediana, Asmara and Cahyowati, 2021). From experience, it often happens that corruption is no longer an isolated problem, but a social problem or 
demand for social change and can be referred to as an anomaly syndrome. That is, a person or official knows that corruption is evil, divisive, disgraceful, sinful, harmful to the state, and much more, but it is still done.

The current president Joko Widodo's leadership has seen the movement to eradicate corruption even slide more backward. His era has seen corruption rise in several official institutions such as in the General Election Commission (KPU), or the Jiwasraya and Asabri cases which resulted in losses of tens of trillions of rupiah. This seems to be a paradox when the country is led by the vision of strengthening the KPK, but the reality is inversely proportional. This shows that the commitment to eradicate corruption has not yet been fully embraced factually. Data released by the KPK in August 2018 indicate 867 state officials / private employees who committed corruption. Of these, 311 were legislators at different levels, governors, regents, and mayors who are almost entirely from political parties. Even the trend of handling corruption cases from 2015 to 2018 has increased quite rapidly. The Indonesia Corruption Watch (ICW) End-of-Year Press Conference, December 2019, presented a final report in 2019 about the corruption eradication agenda. ICW strongly criticized the Joko Widodo government considered not to be pro-corruption eradication. The ICW report is titled 'The Crippling Eradication of Corruption in the Hands of Good People' notes that this is the worst year on the corruption eradication agenda sponsored by President Joko Widodo". ICW presented several crucial notes including President Jokowi breaking promises to strengthen the KPK with the election of a figure without integrity to be the leader of the KPK. "Instead of getting a figure with integrity, the KPK commissioner selection process always selected problematic people," In addition, the ICW also highlighted the birth of the revised KPK Law. The presence of Law No. 19 of 2019. President Joko Widowo deserves to be held as one of the main actors weakening the KPK notably through the Presidential Regulation on the KPK which is now being drafted in the state presidential palace (Lane, 2019; Buehler, 2019; Muhtadi, 2015).

The KPK leadership is also part of state officials at the ministerial level and responsible to the President as head of state. "The presidential regulation that was recently released calls for the KPK to be in an executive institution. This ignores the UN anticorruption convention (UNCAC, 2003) where an independent anti-corruption body is a prerequisite for eradicating corruption". The habit of handing mild verdicts to corruptors also according to ICW is a bad record in the Jokowi era on top of forcing corruption criminal acts into the Criminal Code. According to ICW, that would have bad implications, because it is feared that corruption crime is no longer considered an extraordinary crime but is merely an ordinary or conventional crime. Not only that, but the correctional bill according to ICW also sided with corruptors. Specifically, for the Correctional Draft Bill, ICW assesses that the state has made it easier for corrupt prisoners to access reduced sentences, President Jokowi's statement about the death penalty against corruptors, which he considers to be an outdated narrative. President Jokowi's statement according to ICW was only Jokowi's attempt to avoid public questions related to the KPPU Perppu. The ICW concludes that the state does not want corruption to disappear in Indonesia. ${ }^{5}$

\section{Building an Anti-Corruption Culture Solutions in Eradicating Corruption}

\section{Anti-Corruption Education}

From experience, that corruption is not an isolated problem, but a matter of social participation, a demand for social change is not an option.

Many methods of developing anti-corruption culture have been pointed out and researched by scientists, including building values to change the mindset or paradigm, then forming repetitive behaviors that try and eventually become habits (Yunhai, 2005). Based on this analysis, corrupt habits can be eliminated or at least with promoting anti-corruption culture values. The process is carried out through a planned, systematic, continuous, and integrated education process from an early age to college. The movement against corruption can be effective if it is developed through learning in schools (Komalasari, 2015; Zhang and Lavena, C. 2015; Dewantara et al., 2021). The anti-corruption movement in schools avoids learning the articles of law but emphasizes teaching honesty in everyday aspects. Honesty can be practiced in daily learning without compromising the academic quality of education itself.

There are several levels of action to create an anticorruption culture (Zhanabekova, 2020). The individuallevel at which education must be able to provide awareness and repentance for the sin of corruption.

\footnotetext{
${ }^{5}$ https://kumparan.com/kumparannews/icw-2019-tahun-paling-burukpemberantasan-korupsi-disponsori-jokowi-1sXSwfR02qx 
Second, at the family level where the education is expected to provide a foundation so that the family as the smallest institution will prepare a person to be good and be able to provide good values, bad and can prevent acts of corruption. Thirdly, at the base community level, anti-corruption culture education is very important considering the work environment is not necessarily an arena that destroys values that have been instilled in the family. at the community level, anticorruption education must be a movement to create an understanding that corruption is a common enemy that must be resisted together.

In the context of fostering an anti-corruption culture, the most important thing is the purpose of value education. The basic concept of philosophical anticorruption education is the internalization of the nature of corruption (ontological), understanding of corrupt practices (epistemological), and the application of anticorruption morals in actions (axiological) to prevent corrupt behavior (Miller, 2016; Miller, Roberts and Spence, 2005). Thus, the internalization of anticorruption values through education is an effort to prepare the nation's generation in advancing character, thoughts, actions to fight corruption. Building an anticorruption culture is not as easy as turning the palm.

Early education has a central role in preventing corruption, especially in fostering an anti-corruption culture, increasing legal awareness, and instilling values of integrity in students (Komalasari and Saripudin, 2015). A generation of students who are potential future leaders of the nation needs to be fortified to avoid corrupt behavior or acts of corruption. Elementary school, first and upper level (elementary, junior high, high school, and university), as the second environment that can be a place for character and character development. Education can provide nuances that support efforts to internalize the values and ethics to be inculcated, including anti-corruption behavior. Efforts can be made to instill an anticorruption mindset, attitude, and behavior through teaching because teaching is a civilizing process. Because people born through the education sector are people who uphold the values of truth, have faith, have high moral standards, have competence and professionalism, and can be responsible citizens. When other institutions are powerless to fight against corruption, educational institutions can become the last bastion where anti-corruption values are spread. By way of coaching the mental, spiritual and moral aspects. Education must be used as the front-run pillar to prevent corruption to create clean and good governance for the future. In this article, the author will describe, and explain what should be done through education to foster an anti-corruption culture in Indonesia.

Corruption prevention can be done by improving the legal system, substance, structure, and culture of the community. In addition to improving the legal system, it is also necessary to improve humanity or the culture of the community. In the perspective of legal science, the role of education in both the most basic and highest levels is very central in fostering an anti-corruption culture for the Indonesian people. Lawrence $M$. Friedman explained that legal culture is an atmosphere of social thought, and social power, which determines how the law is used, avoided or misused (Friedman, 1994). Legal culture is closely related to the legal awareness of the community. The higher the legal awareness of the community, then a good legal culture will be created and can change the mindset of the community regarding the law. Eradication of corruption is very dependent on indicators of legal culture adopted by each institution, and law enforcement. Anticorruption culture must be mobilized through legal movements and simultaneously simultaneous sociopolitical movements.

\section{Foster Integrity}

Integrity comes from the Latin from the word "Integer" which means "complete or whole". If we interpret it from the origin of the word, then we can interpret integrity as a complete effort based on honesty, quality, and consistency of the character of a person. In general, integrity is defined as consistency and unwavering determination in upholding noble values and beliefs. Integrity can also be interpreted as a concept that looks at the consistency between action with a value or principle (Schauber, 1996). From an ethical perspective, integrity is said to be the honesty or truth of every person's actions. The opposite of integrity is hypocrisy.

The growth of integrity is a very important influence for the achievement of the culture of law in turning off the direction of the development of acts of corruption. In general, the objectives of fostering an anti-corruption culture are (1) The formation of knowledge and understanding of the forms of corruption and their aspects; (2) Changing perceptions and attitudes towards corruption; and (3) The formation of new skills and skills aimed at fighting corruption. Weak integrity and ethics of those who hold authority are the cause of 
deviations and misuse of authority. Power and governance are the main factors in the successful eradication of corruption. Without power and a government that does not have integrity and is not ethically impossible, the program to eradicate corruption will succeed even if it is supported by good and complete legislation like in Indonesia. Growing Integrity in the community is not like turning the palm. The growth of this integrity must be done through informal and formal education, training, official education, religious activities, disciplinary training, and education that incorporates the noble values of the Indonesian nation both from religion, culture, and national ideology. The implementation of these noble values must be realized concretely in daily life so that eventually it can form a society that is honest, disciplined and can distinguish between her rights and rights for others and can stay away from corrupt mentalities and other irregularities.

A society with integrity is one of the requirements for the realization of anti-corruption (Friedman, 1994). In many countries, the growth of integrity to society is the most effective way of building attitudes and awareness in eradicating criminal acts of corruption. Furthermore, the growth of integrity can provide the realization of good governance. The growth of integrity is a must so that anti-corruption culture can be promoted in all aspects of national and state life.

\section{Revocation of Political and Legal Rights}

\section{Revocation of Political Rights for Corruptors}

Amid the weak sentencing of corruptors, the revocation of political rights can be an alternative to eradicating corruption. Revocation of political rights or disenfranchisement is a legal term that is enforced in the United States. This punishment has existed since Roman times. punishment like this still applies in America. At present, the United States imposes penalties for revoking political rights as criminals. Through the Disenfranchisement Law, criminals are deprived of their political rights. They are not given the right to vote, let alone the right to nominate themselves as senators to be elected. The penalty for revoking political rights is intended to have a deterrent effect on the perpetrators. As well as being used as a sign in the middle of the community so as not to commit a crime. Revocation of political rights is widely discussed in Indonesia, especially by legal experts in criminal acts of corruption. Komnas HAM Senior Staff believes that the revocation of political rights against corruptors is an act that should be supported in order to provide a deterrent effect in eradicating corruption amid low verdicts on corruption cases. Revocation of political rights, especially the right to be elected as a public official, is a form of punishment because the person concerned is not mandated in holding public office and so that he cannot abuse his authority anymore. Political rights themselves are not classified as non-derogable rights. Referring to the Human Rights Law Article 25 of the Covenant on Civil Rights clearly states that the revocation of political rights is "only" related to political positions obtained through general elections, such as positions as members of parliament, regents, governors, and presidents. However, the revocation of political rights cannot be done permanently. There must be a clear limit on how long political rights are revoked. This is following General Comment No. 24 formulated by the United Nations Human Rights Committee that restrictions on political rights must be clear and transparent. Corruption Eradication Commission (KPK) during 2013-2017, the corruption court (tipikor) has revoked the political rights of 26 corruptors who were proven to be involved in corruption cases. The twenty-six people have served as members of the DPR and DPRD, regional heads, and other positions that have great public risk if they become political leaders. Constitutional Law expert Zainal Arifin Mochtar believes that in the Election Law there is no prohibition for corruptors to become candidates, but the law cannot only be interpreted textually. The law must prioritize justice and usefulness (Ross, 2019). How can people who have damaged public trust be given public office again? Corruptors must lose their political rights because ethically they are not obediently nominated and run in the election because they have been named as defendants in corruption cases. Some countries have already started to implement sanctions and no longer even revoke political rights but have already sentenced them to death by being shot as in China, beheaded in Saudi Arabia, life imprisonment in Germany, to the exclusion of people in South Korea. These various punishments are a form of the seriousness of their country in combating corruption. Compared to these countries, the decision to still give the right to be chosen by corruptors may be ironic. Perhaps, at this point, Indonesia's commitment to eradicating corruption is a big question mark. The law of revocation of political rights is based on what is stipulated in Article 10 of the Criminal Code, in the form of revocation of certain rights, the seizure of certain goods, and the announcement of a judge's decision. Revocation of 
political rights refers to the revocation of certain rights, in particular, the revocation of the right to vote and the election is regulated further in Article 35 of the Criminal Code.

In a corruption case, there are additional crimes that can be brought down by judges outside the Criminal Code. Article 18 paragraph (1) of Law No. 31 of 1999 concerning Eradication of Corruption, as amended by Law No. 20 of 2001 has set the additional criminal form in the form of charging replacement money. As an additional crime, revocation of political rights can only be imposed together with the principal crime. So, it can not stand alone without preceded the imposition of basic crimes. Additional crimes in the form of revocation of political rights handed down by the court to several public officials and politicians are a form of commitment to eradicating corruption and a track record that has never been ensnared in a criminal act of corruption.

\section{Revocation of Legal Rights to Corruptors}

In addition to revoking political rights, it is also important to revoke the legal rights of perpetrators of corruption. The sanction of revocation of legal rights will further aggravate the law if viewed from the aspect of sociology. According to the author, legal rights that need to be revoked as additional penalties in the form of revocation of identity (KTP), driver's license (SIM), can not have accounts in government banks, do not get their rights from the government, the right to live properly and so on. Of course all is done by the State with the aim that the anti-corruption program can be successful, and in the future, someone will feel the pain when doing corruption. In the Law of the Republic of Indonesia, the legal rights of citizens have been regulated including the right to decent work and livelihood: "Every citizen has the right to work and a decent living for humanity" (article 27 paragraph 2), the right to live and maintain life: "every person has the right to live and has the right to defend his life and life." (Article 28A), The right to form a family and continue offspring through a legal marriage (article 28B paragraph 1), Right to survival. "Every child has the right to survival, growth, and development." The right to develop themselves and through the fulfillment of their basic needs and the right to education, science, and technology, arts, and culture to improve their quality of life for the welfare of human life. (Article 28C Paragraph 1), the right to advance itself in fighting for their collective rights to develop their society, nation, and state. (Article 28C Paragraph 2), The right to recognition, guarantee, protection, and certainty of law that is fair and equal treatment before the law. (Article 28D Paragraph 1), Right to have private property rights Right to life, right not to be tortured, right to freedom of thought and conscience, right to religion, right not to be enslaved, right to be recognized as private before the law, and right not to be prosecuted based on retroactive law is a human right that cannot be reduced under any circumstances. (Article 281 paragraph 1 ). So, you can imagine how the fate of a corrupt if the legal rights are revoked based on the court's decision of a criminal act of corruption that tries him.

\section{Social Punishment / Sanctions for Corruptors}

Conceptually, social sanctions are a form of punishment aimed at giving shame to perpetrators who violate the values, norms, morality prevailing in society. This discourse re-emerged because of the phenomenon of the defendant and convicted of corruption looking happy, smiling, waving his hands when appearing on the screen. Therefore, positioning the defendant and convict as violators of the value of goodness, moral defects become part to add to the deterrent effect. The form of human or social sanctions for corruptors has not been determined, but several parties who propose for example as street sweepers and wearing special vests can be seen by the public. Another idea is to clean public toilets, identity cards with corruptors, and be employed at the border

To minimize corruption, the discourse on social sanctions should be supported and reinforced by regulation. This can be done by including in the revision of the Criminal Code in particular Article 10 concerning the revocation of certain rights, the seizure of certain items, and the announcement of the judge's decision. If social sanctions are included in the Act, it will certainly be clear the basis of their implementation. In principle, social sanctions do not reduce criminal penalties because they aim to add to the deterrent effect and become a new hope for upholding justice. If social sanctions are effectively implemented, it will become a breakthrough and increase the existing treasury of corrupt penalties such as the elimination of political rights and impoverishment efforts with the provisions of the Criminal Act of Money Laundering (TPPU). This combination will make corruptors poor and no longer have a social position in society. The community must also contribute by not electing corruptors to occupy public positions, not welcoming corruptors who have been released from prison. In the end, if this social sanction is approved by the President 
to be included in the Law Reform Package, it must be applied seriously. Social sanctions must be a 'tool' that provides a deterrent effect on corruptors and does not become a blank document that does not have any impact.

\section{Cutting Generations}

Corruption has tarnished Indonesia's dignity. To eradicate corruption, the method of cutting off one generation in a regime of authority needs to be carried out and become an option to eliminate corrupt cadres and mentally corrupt behavior. Corruption has tarnished Indonesia's dignity and is very difficult to eradicate. "Many leaders (state institutions and agencies) were arrested by the KPK and other legal institutions for corruption," each of them already has land to be corrupted. The existence of every human being will always decrease and increase, alternately. corruption is downstream. Now the corruption is not centralized, all lines are busy with corruption. Cutting one generation can be done by no longer allowing the figure of the corrupt regime to take office again on all leadership lines. The idea of Cut One Generation is an idea that wants to improve the national and social order by changing the structure of thinking that is wrong with the order that it should be. mentality and character of corrupt behaviors.

\section{CONCLUSION}

The culture of anti-corruption law has not been formed in every line of life of Indonesian society, both government officials and at the community level in general, although there are a small number of community groups that remain concerned and resolute to stem the movement of this disease of corruption. Efforts of the Indonesian government in tackling the development of corruption are still assessed at the stage of discourse while empirical facts show that there are large cases that have not been touched by the law. Likewise, the substance of the existing law gives more freedom to the corrupt actors to play their role in eating into the assets and finances of the State. The condition of not developing an anti-corruption culture is one of the factors that cause the chaotic law in Indonesia. Because this legal culture element is an important and influential component in the formation of law and law enforcement of corruption, anti-corruption education efforts must continue to be promoted in a structured, massive and systematic way in addition to other supporters such as fostering integrity at all components of the community level, granting additional law in the form of revocation of political rights and legal rights for those convicted of corruption based on court decisions, social penalties that must be encouraged to continue to be prosecuted as one of the legal norms and an ultimatum remidium effort in the form of a generation of corrupt regime leaders can clean up corrupt behavior in the future generation of the Indonesian nation can be free from corruption can even be deadly to the roots of which the Indonesian people do not know anymore what corruption is.

\section{REFERENCES}

Albab, U. (2007). Kebijakan Publik: Teori, Konsep dan Kajian Akademik.

Belchenko, A., Kurinin, I., \& Teplov, A. (2017, June). History of an Anti-Corruption Struggle Based on the Experience of the Republic of Indonesia. In 2nd International Conference on Contemporary Education, Social Sciences and Humanities (ICCESSH 2017) (pp. 1063-1069). Atlantis Press. https://doi.org/10.2991/iccessh-17.2017.248

Bowen, G. A. (2009). Document analysis as a qualitative research method. Qualitative research journal. https://doi.org/10.3316/QRJ0902027

Buehler, M. (2019). Indonesia takes a wrong turn in crusade against corruption: New legislation will undermine the KPK, but the bigger mistake is conceptual. The Financial Times.

Butt, S. (2017). Corruption and law in Indonesia. Routledge. https://doi.org/10.4324/9780203584729

Choi, J. W. (2011). Measuring the performance of an anticorruption agency: The case of the KPK in Indonesia. International Review of Public Administration, 16(3), 45-63. https://doi.org/10.1080/12294659.2011.10805207

Dewantara, J. A., Hermawan, Y., Yunus, D., Prasetiyo, W. H., Efriani, E., Arifiyanti, F., \& Nurgiansah, T. H. (2021). Anti-corruption education as an effort to form students with character humanist and law-compliant. Jurnal Civics: Media Kajian Kewarganegaraan, 18(1), 70-81. https://doi.org/10.21831/jc.v18i1.38432

Firmansyah, M. F. (2021). Impact of Political Institution Role to AntiCorruption Perception Index: An Experience From Indonesia. International Journal of Community Service \& Engagement, 2(1), 20-41.

Friedman, L. M. (1994). Is there a modern legal culture?. Ratio Juris, 7(2), 117-131. https://doi.org/10.1111/j.1467-9337.1994.tb00172.x

Hamilton-Hart, N. (2001). Anti-corruption strategies in Indonesia. Bulletin of Indonesian Economic Studies, 37(1), 65-82. https://doi.org/10.1080/000749101300046519

Harijanti, S. D. (2014). The evolution of the Indonesian Ombudsman system. International Journal of Public Law and Policy, 4(1), 37-52. https://doi.org/10.1504/IJPLAP.2014.057885

Harrison, E. (2017). The 'cancer of corruption'. In Between Morality and the Law (pp. 143-162). Routledge. https://doi.org/10.4324/9781315261683-14

Juwono, V. (2018). The History of Governance Reform and the AntiCorruption Measure under Guided Democracy Era: Indonesia Experience in 1957-1967. BISNIS \& BIROKRASI: Jurnal IImu Administrasi dan Organisasi, 24(2).

Kinanti, K. (2020). The Establishment of KPK Supervisory Board towards the Eradication of Corruption by KPK (Doctoral dissertation, Universitas Gadjah Mada). 
Komalasari, K., \& Saripudin, D. (2015). Integration of anti-corruption education in school's activities. American Journal of Applied Sciences, 12(6), 445. https://doi.org/10.3844/ajassp.2015.445.451

Komalasari, K., \& Saripudin, D. (2015). Integration of anti-corruption education in school's activities. American Journal of Applied Sciences, 12(6), 445. https://doi.org/10.3844/ajassp.2015.445.451

Lane, M. (2019). President Joko Widodo's New Cabinet: Some Implications for Indonesian Politics. ISEAS Perspective, (2019/99), 2019.

Lukito, A. S. (2016). Building anti-corruption compliance through national integrity system in Indonesia: A way to fight against corruption. Journal of Financial Crime. https://doi.org/10.1108/JFC-09-2015-0054

Mediana, F. R. I., Asmara, M. G., \& Cahyowati, R. R. (2021). The Corruption Eradication Commission's (KPK) Position and Function in the Indonesian State System. International Journal of Multicultural and Multireligious Understanding, 8(11), 345-358.

Miller, S. (2016). Corruption and Anti-corruption in Policing-Philosophical and Ethical Issues. Dordrecht: Springer. https://doi.org/10.1007/978-3-319-46991-1

Miller, S., Roberts, P., \& Spence, E. (2005). Corruption and anticorruption: An applied philosophical approach. Pearson Prentice Hall.

Muhtadi, B. (2015). Jokowi's first year: a weak president caught between reform and oligarchic politics. Bulletin of Indonesian Economic Studies, 51(3), 349-368. https://doi.org/10.1080/00074918.2015.1110684

Paldam, M. (2002). The cross-country pattern of corruption: economics, culture and the seesaw dynamics. European Journal of Political Economy, 18(2), 215-240. https://doi.org/10.1016/S0176-2680(02)00078-2
Ross, A. (2019). On law and justice. Oxford University Press. https://doi.org/10.1093/oso/9780198716105.001.0001

Schauber, N. (1996). Integrity, Commitment and the Concept of a Person. American Philosophical Quarterly, 33(1), 119-129.

Sidi, R. (2019). Corruption Prevention Efforts with Non Penal Policy. Britain International of Humanities and Social Sciences (BloHS) Journal, 1(1), 53-63. https://doi.org/10.33258/biarjohs.v1i1.10

Stulhofer, A., Kufrin, K., Caldarovic, O., Gregurovic, M., Odak, I., Detelic, M., \& Glavasevic, B. (2008). Corruption as a cultural phenomenon: Expert perceptions in Croatia. Discussion Paper Series No. 11.

Transparency International. (2019). Corruption perception index [CP 2019].

Turner, M., Prasojo, E., \& Sumarwono, R. (2019). The challenge of reforming big bureaucracy in Indonesia. Policy Studies, 1-19. https://doi.org/10.1080/01442872.2019.1708301

UNCAC 2nd, I. R. M., \& Harutyunyan, N. (2003). United Nations convention against corruption.

Yunhai, W. (2005). Corruption and Anti-Corruption Policy in Today's. Hitotsubashi journal of law and politics, 33, 1-5.

Zhanabekova, E. (2020). Formation Of An Anti-Corruption Culture In Society. In Scientific Achievements and Discoveries 2020 (pp. 197-199).

Zhang, Y., \& Lavena, C. (Eds.). (2015). Government anti-corruption strategies: A Cross-cultural perspective. CRC Press. https://doi.org/10.1201/b18560

Zouaoui, A., Al Qudah, A., \& Ben-Arab, M. (2017). World corruption perception index analysis. Research Journal of Finance and Accounting, 8(24).

Received on 22-10-2021

Accepted on 02-12-2021

Published on 07-12-2021

https://doi.org/10.6000/1929-4409.2021.10.174

(C) 2021 Syah and Malik; Licensee Lifescience Global.

This is an open access article licensed under the terms of the Creative Commons Attribution License (http://creativecommons.org/licenses/by/4.0/) which permits unrestricted use, distribution and reproduction in any medium, provided the work is properly cited. 